\title{
Use of the Objective Structured Clinical Examination in Undergraduate Nursing Education
}

1 Martina Smrekar

1 Sanja Ledinski Fičko

1 Ana Marija Hošnjak

1 Boris Ilić

1 University of Applied Health Sciences, Department of Nursing, Mlinarska cesta 38, 10000 Zagreb, Croatia

Article received: 18.04.2017.

Article accepted: 21.07.2017.

Author for correspondence:

Martina Smrekar

University of Applied Health Sciences

Mlinarska cesta 38, Zagreb, Croatia

Phone: + 385914595711

Fax: + 38515495711

E-mail: martina.smrekar@zvu.hr

DOI: $10.24141 / 2 / 1 / 1 / 8$

Keywords: OSCE (Objective Structured Clinical Examination), nursing education, clinical skills

\section{Abstract}

Introduction. The Objective Structured Clinical Examination (OSCE) is often used in undergraduate nursing education as a means to provide standardised and objective evaluation of clinical skills required for nurses' future professional activity. It aims to help students master different clinical skills and prepare them for an adequate response to specific problems through simulation of various practical scenarios. Students practice clinical skills in a safe and controlled environment under the supervision of a mentor. Since the mid-1970s, OSCE has been used to assess clinical skills of medical students. From then until today, it has been applied in evaluating different profiles of health professionals, especially nurses.

Aim. The purpose of this paper is to present scientific evidence regarding the benefits of OSCE in undergraduate nursing education. The aim of this paper is to analyse findings on the use of OSCE in undergraduate nursing education worldwide, as well as students' and educators' perception of the OSCE examination.

Methods. A systematic review of articles published in MEDLINE, regarding the use of OSCE in nursing education, and students' and educators' perception of the OSCE examination, was carried out in the period between 2005 and 2017.

Results. In total, 8 articles were taken into consideration. These studies were selected because they provided information on the use of OSCE in nursing 
education worldwide and students' and educators' perception of the OSCE examination.

Conclusion. The application of OSCE has multiple benefits for nursing students. It can easily assess the knowledge and performance of clinical skills important for nursing practice. It serves to better prepare students for their professional activity.

\section{Introduction}

Nurses are the largest group of health care professionals. During their education, undergraduate nursing students should acquire skills necessary for future professional activity (1). The European Qualifications Framework describes skills as cognitive (involving the use of logical, intuitive and creative thinking) or practical (involving manual dexterity and the use of methods, materials, tools and instruments) (2).

Assessment of clinical competence is an essential requirement of health professional education (3). According to Miller (1990), the assessment of the performance of clinical skills should be designed in such a way that students are tested in terms that are related to their future professional function. The template for the development of clinical skills is described in a way that outlines the four levels that must be taken into account: the student knows, knows how, shows how, and does. The first and the second level include multiple-choice questions, essays, and an oral exam; the third level includes simulation and the OSCE exam; the fourth level involves the assessment of the actual real-world environments $(3,4)$.

During education, nursing students learn how to perform clinical skills necessary for their future professional activity by using simulation-based learning in nursing skills demonstration rooms. Here, students encounter different equipment and materials that are required in the clinical setting. Simulation-based education can be performed on multi-functional manikins (human body or parts of the body where students can perform measurement of vital signs, urinary catheterization, injection administration, etc.). Students gain confidence in performing clinical skills in a simulated environment before performing the same skills in the actual clinical settings. They must possess knowledge of specific skills and know how to apply this knowledge into practice through proper performance of clinical skills. Educators are obliged to give students feedback on their knowledge, point to deficiencies in knowledge and give suggestions on how to improve the performance of clinical skills. Educators supervise the performance of each student and their progress in the acquisition of knowledge, skills and attitudes. For a more objective approach to the assessment of knowledge, skills and abilities of students for professional activity, educators often use the Objective Structured Clinical Examination (OSCE).

The Objective Structured Clinical Examination (OSCE) is defined as an "approach in the assessment of clinical expertise in which competencies are estimated in a well-planned and structured manner, with special attention paid to objectivity" $(3,5)$. The OSCE was first mentioned in 1975, when the authors Harden et al. published a paper in the British Medical Journal about the assessment of clinical competence using the Objective Structured Clinical Examination. The aim of the study was to assess the basic clinical skills of medical students through the Objective Structured Clinical Examination. The first OSCE examination was conducted at a hospital ward. The test was designed in such a way that the students had several stations where they had to perform a particular task. At each station, they received written instructions on how the task should be performed (for example: do part of the physical examination, interpret laboratory results, etc.). Students had exactly five minutes to perform a particular task. After the given time, the students had to go to the next station where they answered questions related to the previous workstation. The whole process was accompanied by examiners who were evaluating the students' performance using checklists. Students accessed between 16 and 20 workstations (5).

\section{Performance of an OSCE}

OSCE is used as a method for assessing knowledge and skills in performing clinical skills required for nursing practice. It is performed in a safe environment where certain skills can be applied to multifunctional manikins or other students through simulation or role playing. According to Milutinovic (2013), the use of OSCE in nursing education has increased in the past 10 years (6). 
As previously stated, OSCE stands for:

Objectivity - educators use a predefined checklist for the evaluation of students. The checklist is written in a standardised way. It should be valid, i.e. measure knowledge of the student. Measurement should be objective (not dependent on the examiner), reliable (that is, more measurements result in the same or similar data), sensitive (allows for differentiation in the results of the variables to be measured). Structured - all students have the same tasks that must be solved in the same time frame. Clinical - tasks that are put before students are identical to actual clinical situations. Examination - assessment of skills using a formal test of knowledge or skills.

According to Alinier (2003), the OSCE is composed of 15-20 short exercises or stations where students rotate individually. The number of candidates taking part in the session is determined by the number of stations. The assessment period usually lasts between 3 and 10 minutes and can be alternated with short rotation intervals so that students have time to move to the following exercise (7). Adequate preparation of students is required before conducting OSCE. Preparation involves identification of students, explaining of the purpose of the examination and OSCE rules, bringing students to the initial place of testing, and the introduction to the workstations, equipment and materials. After that, the student gets clear instructions about the task that needs to be done. During OSCE, educators evaluate students' approach to the patient, their communication skills, the interaction between the student and the simulated patient. Students are expected to introduce themselves to the patient, thoroughly explain the process to the patient, obtain consent for the procedure, implement specified procedures, take care of the patient, accessories and document the entire process. Each student performs the same tasks in the same time frame. The examiner evaluates the students according to pre-set criteria thereby making the examination structured and objective (8). Educators monitor the performance of certain skills and provide feedback to students about their success in performing those skills, but also show students their mistakes and the cause of those mistakes. Students become aware of their strengths and weaknesses in performing clinical skills and get feedback on how to correct them. This guides students towards active learning, critical thinking and contributes to the development of safe practice. The OSCE assessment can be used for formative assessment (assessment can track the performance of certain skills during the teaching process) or summative assessment (assessment can evaluate the performance of certain skills after the completion of the teaching process) (9).

\section{Advantages of the OSCE assessment}

Advantages of the OSCE assessment: this method allows for an interesting teaching process, and it also encourages students to become active participants in the learning process. It encourages the development of critical thinking and logical reasoning which results in having a competent and efficient nurse. The test is carried out in a controlled environment without compromising patient safety. Students are evaluated in a pre-defined manner to avoid the subjectivity of educators. Students learn about the tools which are used to perform a certain skill and they can develop confidence in clinical skills without compromising patient safety. According to Alinier (2003), the greatest advantage of using OSCEs are the stations. The stations can be organized in the form of mini scenarios, simulations, case studies, multiple choice questionnaires, short theoretical questions, or even rest stations to help the students relax from time to time (7).

\section{Disadvantages of the OSCE assessment}

Disadvantages of the OSCE assessment are the following: it is financially demanding, it is necessary to invest more time in the preparation and organization of the exam, it creates a competitive atmosphere and some students find it stressful.

The importance of using OSCEs as an assessment method in nursing education has been described by numerous authors:

- Our experience suggests that the OSCE may be a powerful tool in the evaluation of clinical competence in nursing and that it may also be an effective facilitator for learning to perform clinical skills in nursing (10).

- OSCEs can be used most effectively in nurse undergraduate curricula to assess safe practice in terms of performance of psychomotor skills, as well as the declarative and schematic knowledge associated with their application. OSCEs should be integrated within a curriculum in conjunction with other relevant student evaluation methods (3). 
- An OSCE is a necessary assessment tool that should be continuously applied in nursing education, regardless of the mode of the education program, the student's years of experience or his/her clinical placement (11).

- Objective structure Clinical Examination (OSCE) is a more sophisticated examination method to assess competencies such as problem-solving abilities, critical thinking and communication skills, and has gained acceptance as a benchmark for clinical skills assessment (8).

- The OSCE is an assessment tool that can provide high-impact training to students. From its creation to the present, the Objective Structured Clinical Examination (OSCE) has been regarded as an effective assessment tool (12).

- The OSCAs were seen as a good assessment tool, which gave students the opportunity to receive feedback on their performance in relation to clinical skills (13).

- The Objective Structured Clinical Exam is designed to assess the knowledge, skills and abilities in a clinical setting. It represents an effective strategy for measuring the success of implementation of clinical skills in a safe and controlled environment (14).
- The Objective Structured Clinical Examination (OSCE) is an established tool in the repertoire of clinical assessment methods in nurse education. The use of OSCEs facilitates the assessment of psychomotor skills as well as knowledge and attitudes. Identified benefits of the OSCE assessment include development of students' confidence in their clinical skills and preparation for clinical practice (15).

- A well-designed and implemented OSCE can provide students with opportunities to demonstrate interpersonal and interview skills, problem-solving abilities, teaching, assessment skills, and application of basic clinical knowledge $(16,17)$.

The purpose of this paper is to present scientific evidence regarding the benefits of OSCE in nursing education. The aim of this paper is to analyse the findings about the use of OSCE in nursing education worldwide, and students' and educator' perception of the OSCE examination.

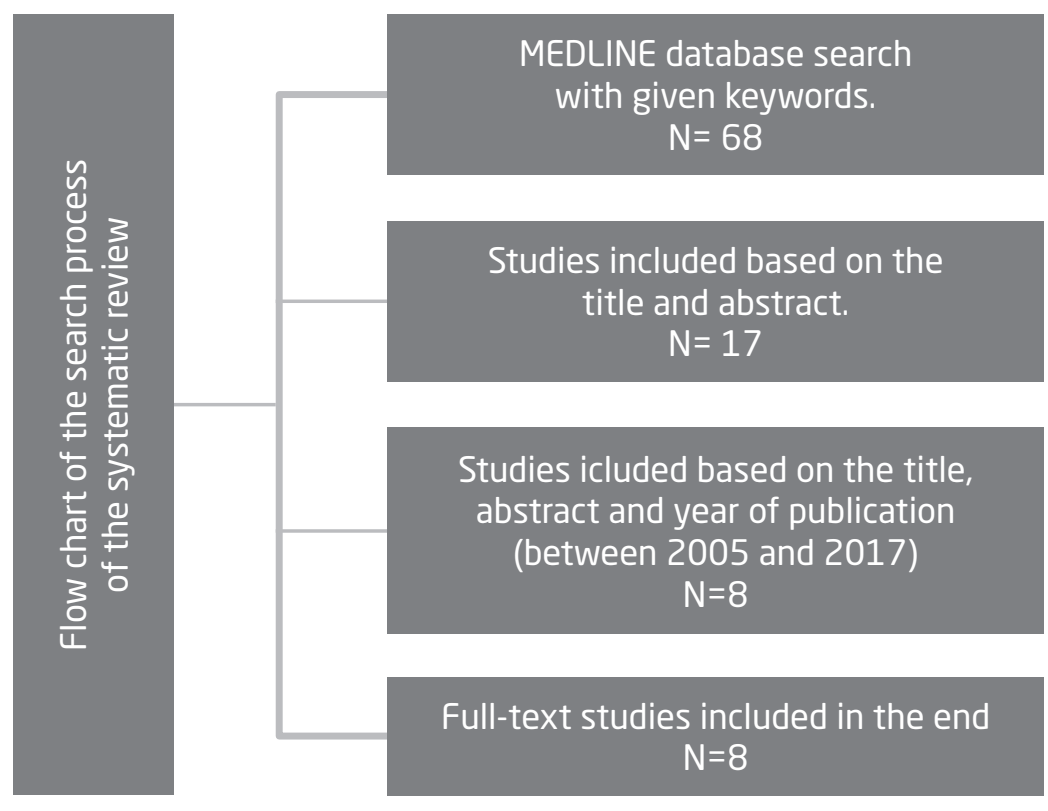




\section{Methods}

The study is a systematic review of articles published in MEDLINE, regarding the use of OSCE in nursing education worldwide, and students' and educators' perception of the OSCE examination.

\section{Inclusion and exclusion criteria}

We included the original articles relating to countries worldwide which describe the use of OSCE in nursing education and students' and educators' perception of the OSCE examination. The inclusion criteria were also the articles written in the English language and original articles relating to specific countries worldwide with the year of publication between 2005 and 2017. We excluded the studies with the year of publication prior to 2005.

\section{Search strategy}

Literature search was carried out between January and March 2017 using the MEDLINE database. The search included the following terms: clinical competency assessment, objective structured clinical examination, nursing education, using Boolean operators "AND". Search results included 68 studies.

The first step was the analysis of the list of the titles of articles which could be potentially included, based on the keywords that were entered into the database. The second step was to analyse the articles that correspond to the title. The third step was the analysis of the abstracts that matched the title and the year of publication between the 2005 and 2017. In total, 8 full-text studies were included in this systematic review. The results of this review are displayed in tabular form.

\section{Results}

The search strategy identified 68 studies. A total of 8 studies with details about the use of OSCE in undergraduate nursing were included in this review.
Of the eight studies included in the review, one study was from Spain (12), one from Italy (18), one from the USA (16), two were from the United Kingdom $(17,19)$, one from Egypt (20) and two from Ireland $(15,21)$.

All the studies provide descriptions related to the use of OSCE in nursing education, and details about the organisation of the OSCE exam. Some of the studies provide a description of educators' (12) or students' perception of the OSCE exam (15).

Authors Solà, Pulpón, Morin, Sancho, Clèries and Fabrellas (2017) conducted a study to identify Nursing School faculty perceptions regarding the implementation of OSCE as an assessment tool. They concluded that OSCE should be administered towards the end of the degree program as a part of a multimethod evaluation strategy for student assessment. Authors stated that OSCE with adequate feedback can provide high-impact training to students (12).

Authors Bagnasco, Tolotti, Pagnucci, Torre, Timmins, Aleo and Sasso (2016) used OSCE as a method to assess communication skills using two examiners who conducted their assessment separately. They stated that OSCE proved as a useful method to assess communicative skills (18).

In most cases, the OSCE has been conducted traditionally, using paper-based methodology. Authors Meskell, Burke, Kropmans, Byrne, Setyonugroho and Kennedy (2015) pointed out the benefits of using an electronic OSCE management system which saved time, thus preventing documentation errors and providing student feedback about their performance (15).

Authors Traynor and Galanouli (2015) described the Angoff standard-setting procedures that were used to calibrate OSCE at the United Kingdom University. According to authors, it was the first OSCE in the UK to incorporate a scientific standard-setting procedure (17).

Rush, Ooms, Marks-Maran and Firth (2014) tried to identify students' experiences with OSCA with immediate feedback to students. They concluded that OSCA enhances learning and increases students' confidence (19).

Selim, Ramadan, El-Gueneidy and Gaafer (2014) tested the first application of OSCE in undergraduate psychiatric nursing education in Egypt. Authors stated that the psychiatric nursing OSCE proved to be a reliable and valid method in assessing psychiatric nursing clinical competencies (20). 

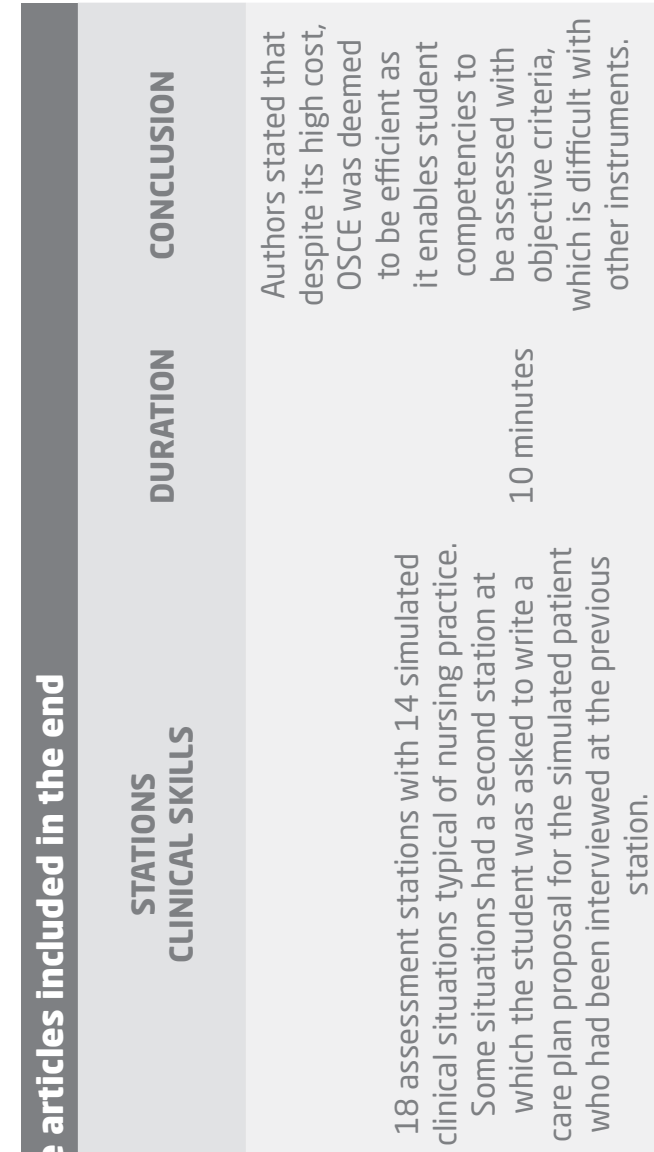

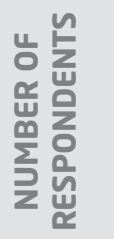

点

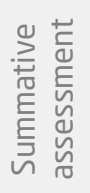

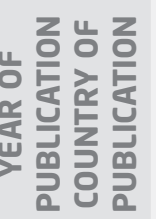
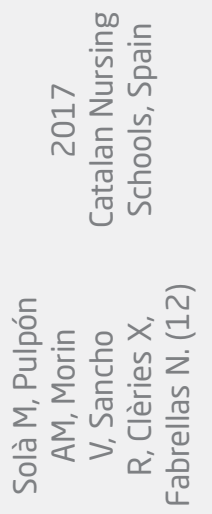

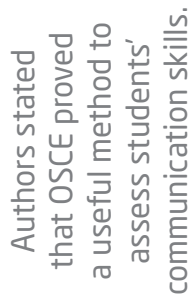

氖

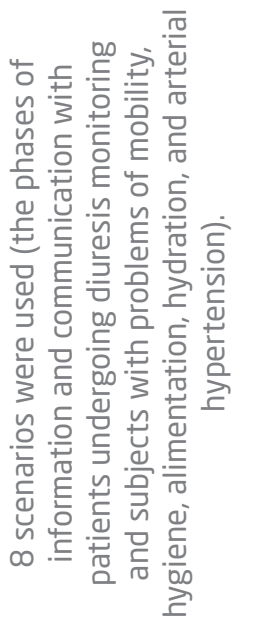

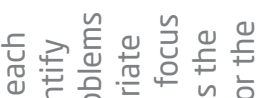

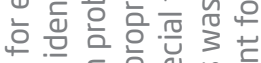

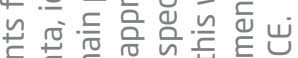

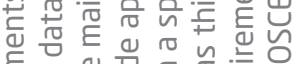

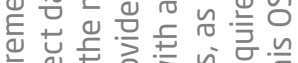

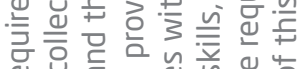

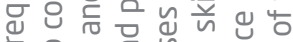

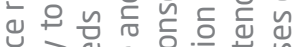

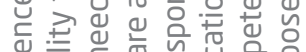

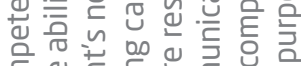

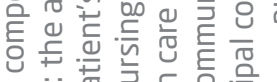

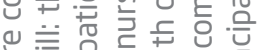

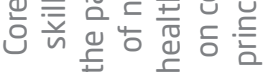

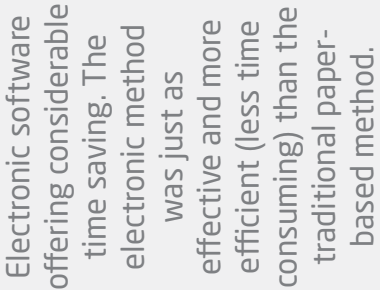

吕
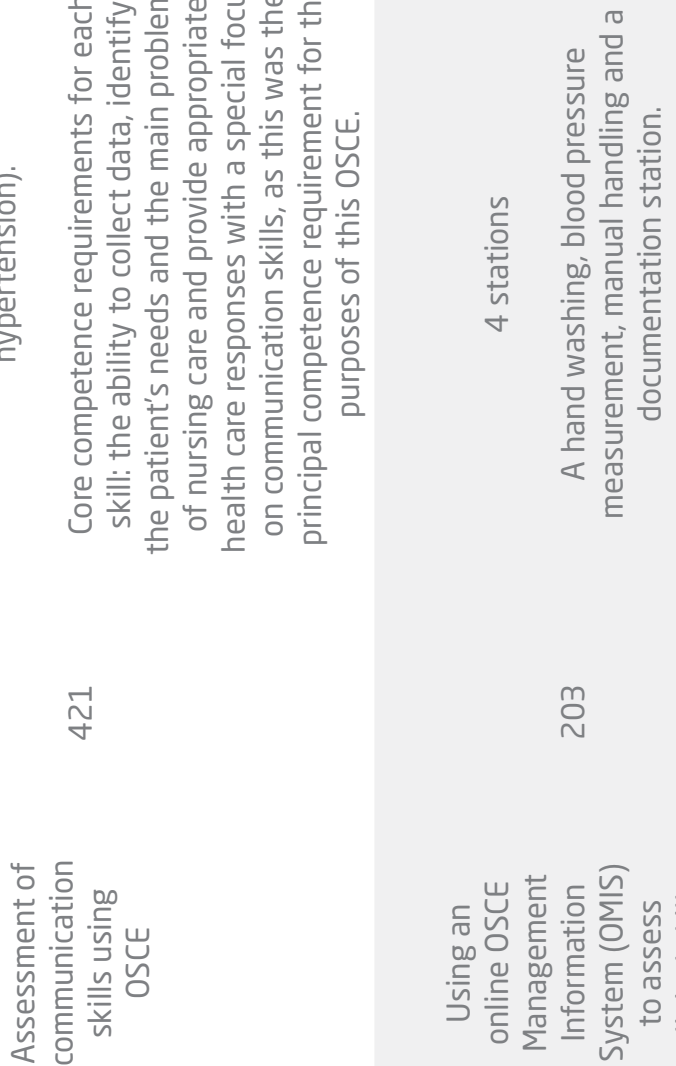

$\stackrel{\check{ษ}}{\sim}$

$\stackrel{m}{\sim}$
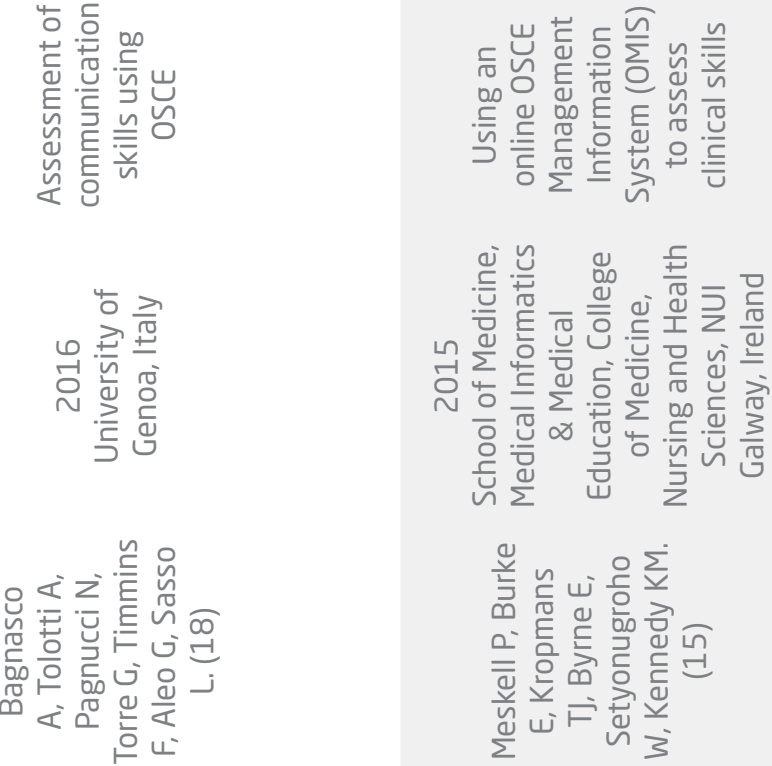

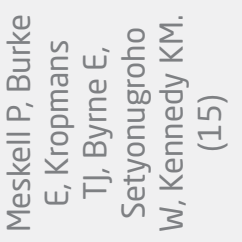




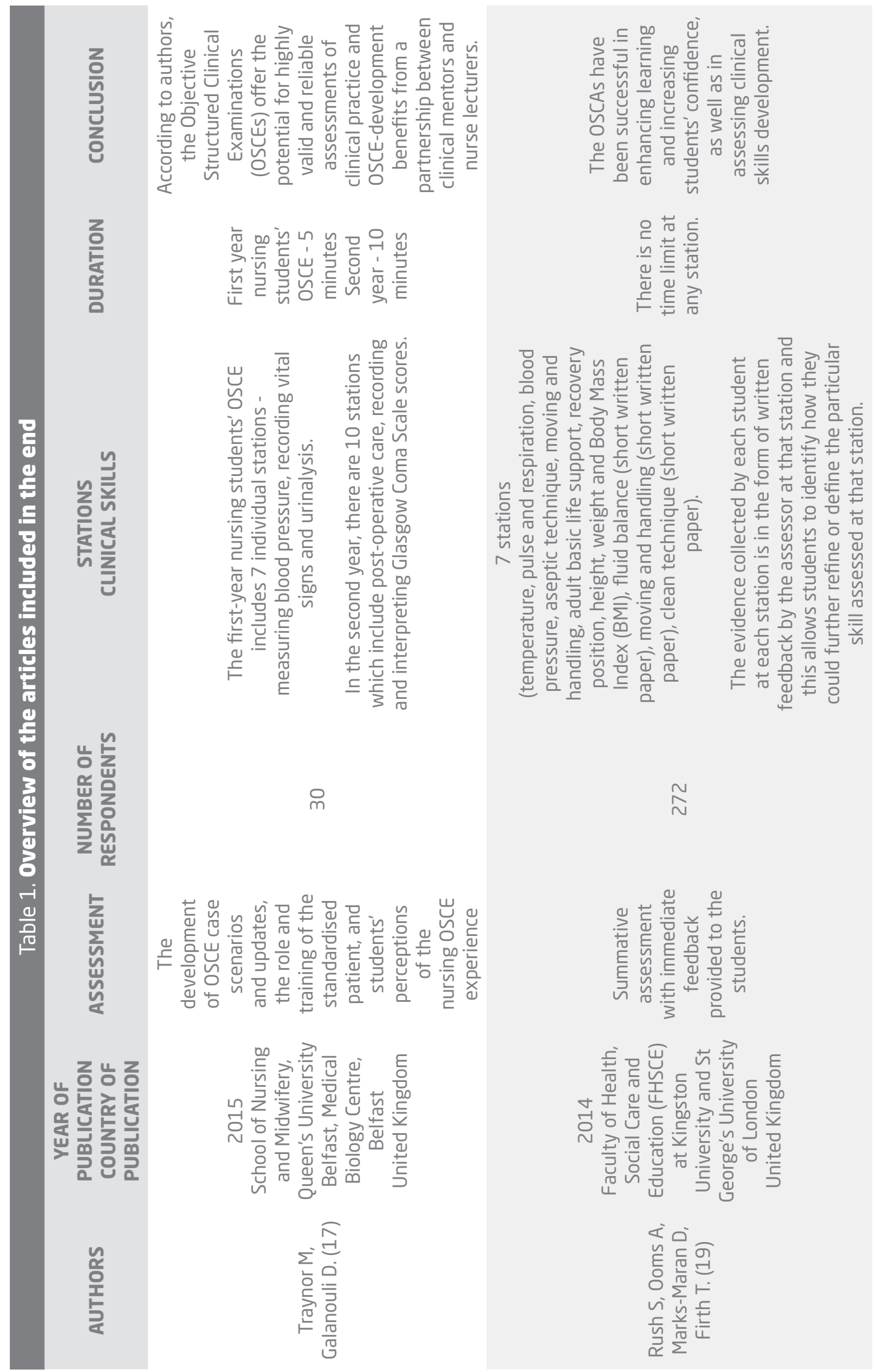



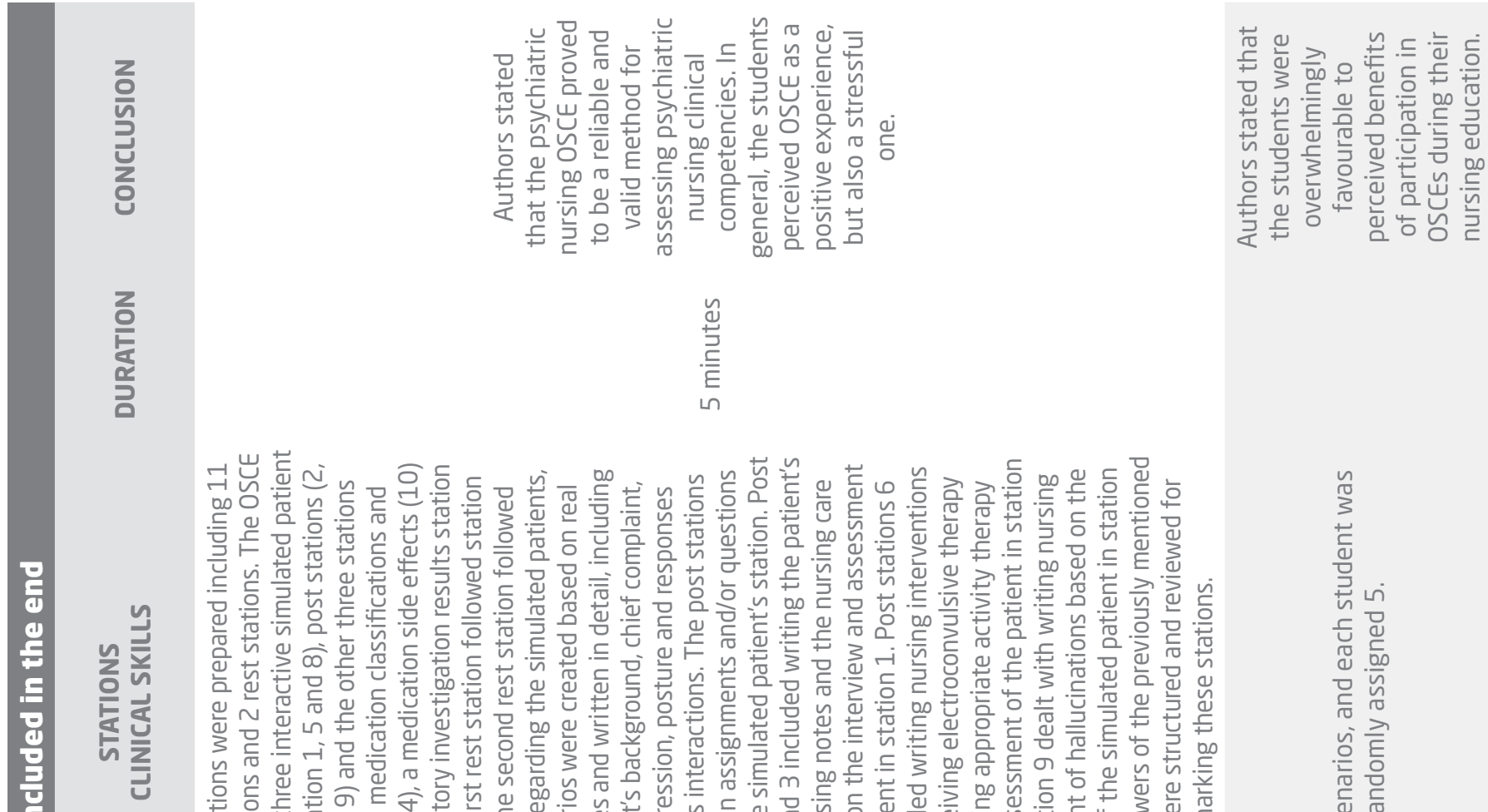

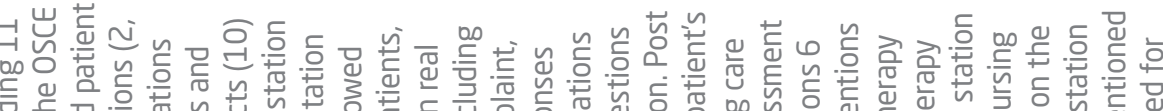

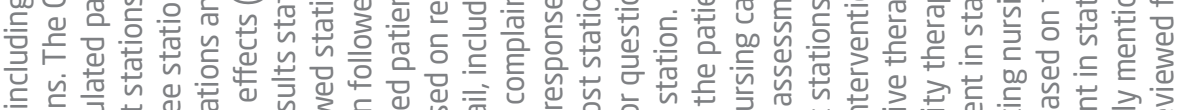

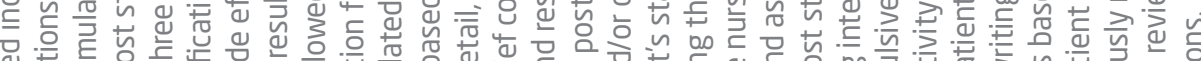

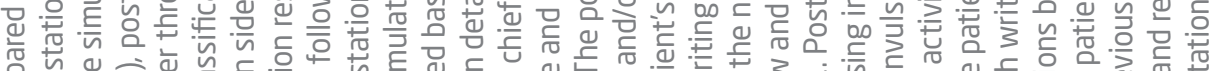

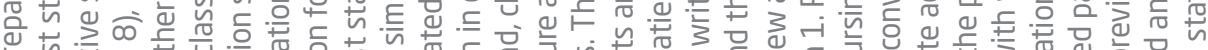

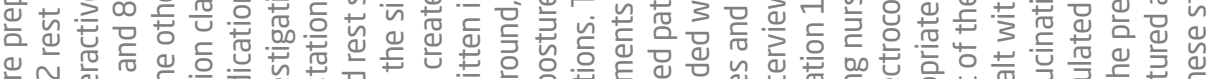

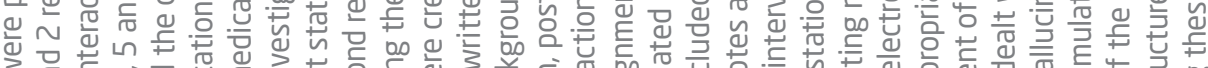

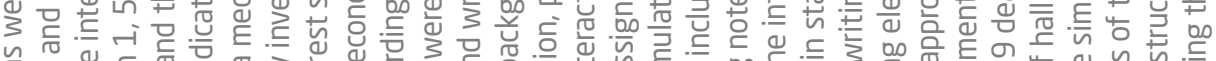

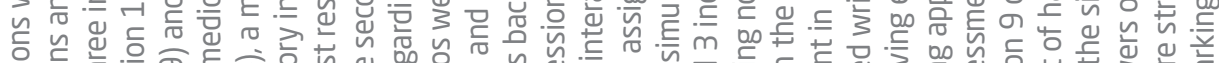

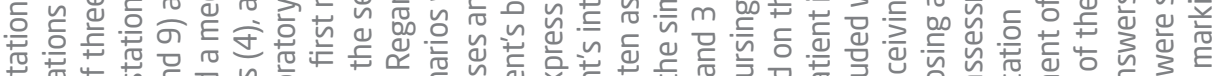

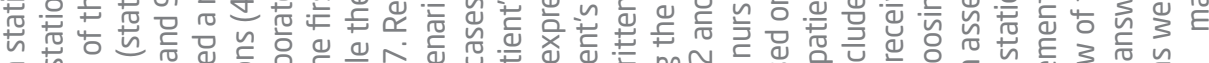

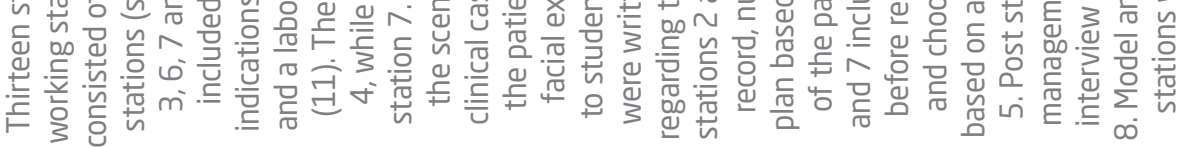

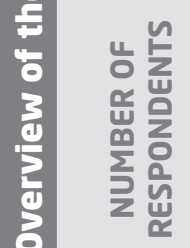

$\stackrel{m}{-}$

กั

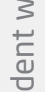

谒

喜

믄

은

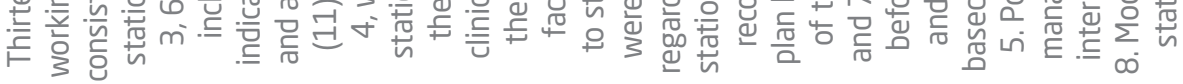

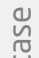

苍

우

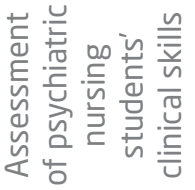

突

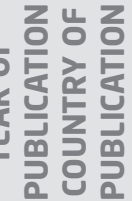
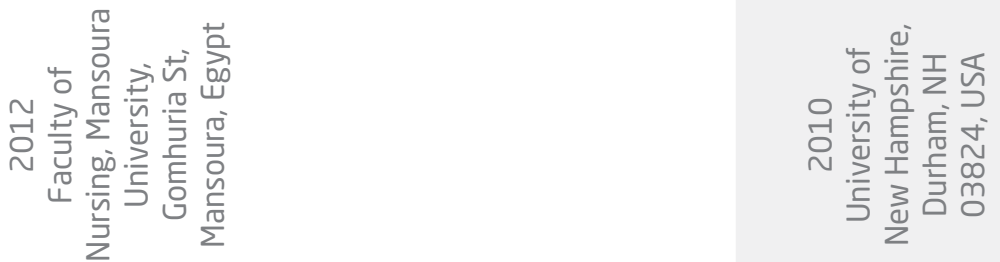

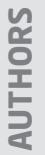
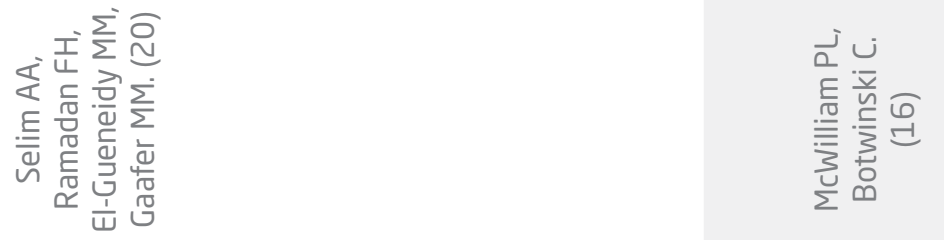


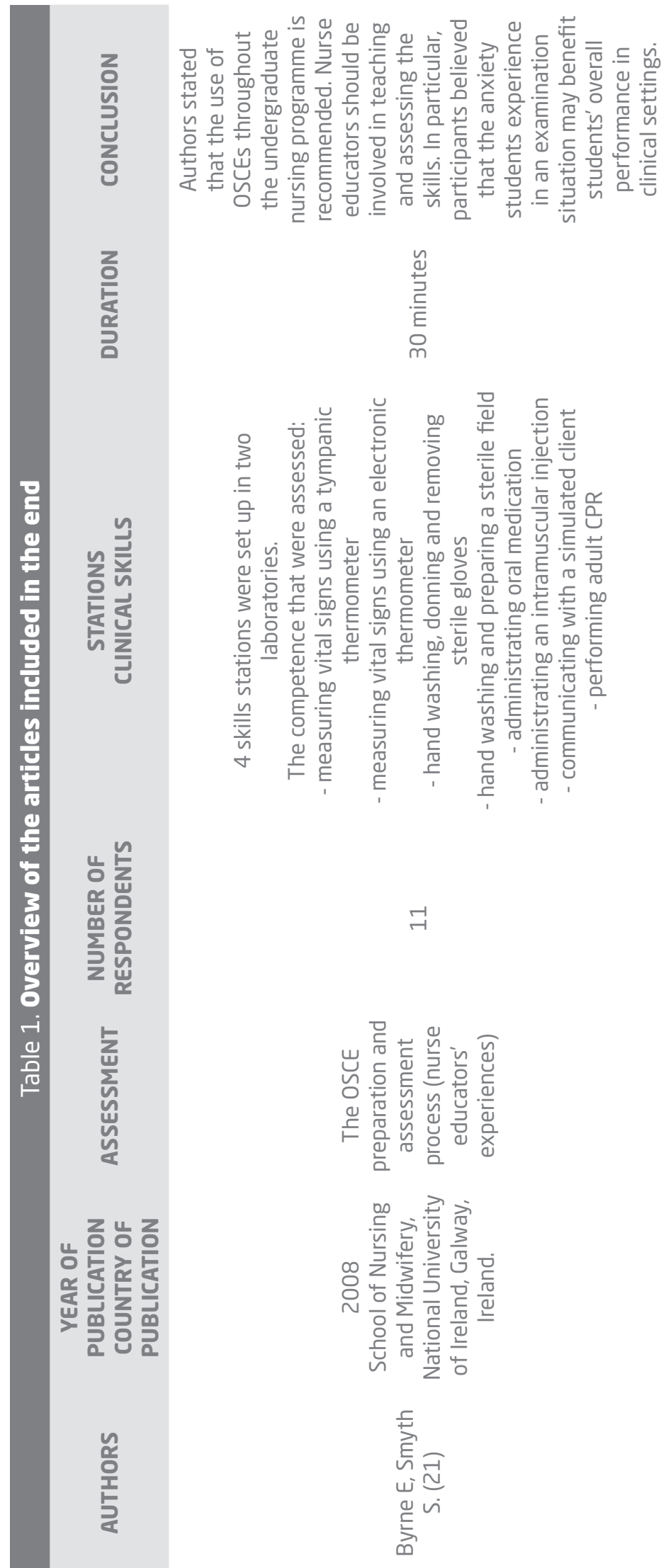

McWilliam and Botwinski (2010) conducted an OSCE formative evaluation of students' clinical competencies. Authors investigated the development of case scenarios and updates, the role and training of the standardised patient, and students' perceptions of the nursing OSCE experience. Students perceived benefits of participation in OSCE during their nursing education (16).

Byrne and Smyth (2008) in their study wanted to analyse nurse educators' experiences and perspectives of assessing students' clinical competence using OSCE and to address the challenges of executing the examination. Authors stated that the use of OSCE throughout the undergraduate nursing programme was recommended (21).

\section{Discussion}

In order to improve nursing education, different teaching methods are adopted to help students gain knowledge, skills and attitudes relevant for nursing practice more easily. The use of simulation-based learning helps students develop a sense of safety when performing certain tasks. The assessment of clinical skills is very important in nursing education. Therefore, OSCE is seen as a good assessment tool and an objective, valid strategy for assessing nursing students' clinical competences in a safe and controlled environment. The purpose of this paper is to present scientific evidence regarding the use of OSCE in undergraduate nursing education. OSCE can be designed as different simulated clinical scenarios or it can be implemented through role-playing using standardised patients or manikins. It is used for better implementation of theoretical knowledge in practice. The results of this study indicate that OSCE can be used for summative or formative evaluation of competences. According to Solà, Pulpón, Morin, Sancho, Clèries and Fabrellas (2017), OSCE should have a summative 
and formative purpose - enhancing the feedback received by students about their performance - and should carry weight regarding students' academic records to ensure their involvement (12). According to many authors $(3,8,10-17)$, OSCE contributes to quality education for undergraduate nursing students. There are many advantages for both teachers and students. The competencies can be assessed with objective criteria (13), it is a useful method to assess students' communication skills (19), it enhances learning and increases students' confidence (19), and ensures safe practice (20). It offers the potential for valid and reliable assessments $(17,20)$.

The use of OSCE throughout the undergraduate nursing programme is recommended (21). Student preparation plays an important role when preparing OSCE (17). Students have reported that they perceived OSCE as a positive experience (15), and, but also a stressful one $(15,20)$. If students perceive OSCE as very stressful, it can affect their effectiveness in the execution. Students verbalize a greater level of confidence in performing skills after they pass the OSCE exam (16). One of the benefits of OSCE is that educators can provide students with feedback on their performance (15). Authors Rush, Ooms, Marks-Maran and Firth (2014) stated that at the St. George's University of London, United Kingdom, OSCEs were universally disliked by students, for reasons that included absence of immediate feedback. The feedback was provided to the students after several weeks, because it was policy for results to be ratified by the examinations board before giving the final marks/ grades to students. After a while, the University rebranded OSCE as an objective structured clinical assessment (OSCA) with immediate feedback provided to students. Authors stated that OSCA with immediate feedback was perceived positively by students, was valued with regard to a number of factors, had a positive impact on student learning and confidence and was regarded as a form of assessment which the University should continue to use (19). This contributes to the satisfaction of students and raises the quality of education. Certain studies emphasize that the preparation and organization of the OSCE exam is demanding. Considerable challenges are required to ensure the validity and reliability of the process (14). Educators must assure reliability and validity of the OSCE exam. For that reason, some authors indicate the importance of using two examiners per station to achieve objectivity in the OSCE exam $(14,18)$. This way of testing can result in exhaustion of examin- ers if they have many students. Authors Traynor and Galanouli (2015) stated that from the beginning of the nursing OSCE-development process, their school involved clinical mentors in the assessment process and OSCE-development benefited from a partnership between clinical mentors and nurse lecturers (17). Different approaches have been used in implementing OSCE in the teaching process.

OSCE is used in nursing practice worldwide. For example, in Canada, internationally educated nurses (IENs) who want to apply for a nursing position in Canada, must submit the application and supporting documents to the College of Nurses of Ontario (CNO) for assessment. The College of Nurses of Ontario evaluates all international nurse applicants to determine if knowledge, skills and judgment are equal to that of a recent graduate of an Ontario undergraduate nursing program using OSCE. The (OSCE) results determine whether the applicant has demonstrated entry-to-practice competencies to meet the program requirement (22).

\section{Conclusion}

It is necessary to ensure the quality of nursing education as a basis for providing better quality care for patients and safe practice. This can be achieved by using OSCE as part of undergraduate nursing education. This study wishes to emphasize the importance of applying OSCE in the education of nurses. The application of OSCE has multiple benefits for nursing students. Some of the advantages of such an assessment are that OSCE is used to easily assess the knowledge, skills and attitudes of nursing students in a simulated clinical environment similar to a real clinical setting without compromising patient safety. The aim of this is to help nursing students to be better prepared for their future role. The use of OSCE is described in undergraduate nursing education worldwide. The application of OSCE differs in different countries. 


\section{References}

1. Čukljek S. Sestrinstvo, znanje i izvrsnost. In: Čukljek S, Turuk V, editors. Zbornik radova 10. konferencije medicinskih sestara „Znanjem do izvrsnosti”; 25.-27. ožujak 2010; Opatija, Hrvatska. Zagreb: Zdravstveno veleučilište Zagreb;2010. Croatian.

2. European Qualifications Framework - EQF. Learning opportunities and qualifications. Descriptors defining levels in the European Qualifications Framework (EQF). Available form: https://ec.europa.eu/ploteus/en/content/descriptors-page Retrieved: 14.02.2017.

3. Mitchell ML, Henderson A, Groves M, Dalton M, Nulty D. The Objective Structured Clinical Examination (OSCE): Optimising its value in the undergraduate nursing curriculum. Nurse Educ Today. 2009;29(4):398-404. https:// doi.org/10.1016/j.nedt.2008.10.007

4. Miller GE. The assessment of clinical skills/competence/ performance. Acad Med. 1990;65(9 Suppl):63-7.

5. Harden RM, Stevenson M, Downie WW, Wilson GM. Assessment of clinical competence using objective structured examination. Br Med J. 1975; 22;1(5955):447-51.

6. Milutinovic D. Assessing clinical skill competence of nursing students through Objective Structured Clinical Examination. SEEHSJ 2013; 3(1):13-8.

7. Alinier G. Nursing students' and lecturers' perspectives of objective structured clinical examination incorporating simulation. Nurse Educ Today. 2003; 23(6): 419-26.

8. Sleem WF, El-Shaer AM, Elatroush HG. Does implementing for an Objective Structure Clinical Examination make a difference? Med. J. Cairo Univ.2012; 80(2): 239-47.

9. Vizek Vidović V, Rijavec M, Vlahović Štetić V, Miljković D. Psihologija obrazovanja. IEP d.o.o. Zagreb: Vern;2003. Croatian.

10. Ross M, Carroll G, Knight J, Chamberlain M, FothergillBourbonnais F, Linton J. Using the OSCE to measure clinical skills performance in nursing. J Adv Nurs. 1988;13(1):45-56.

11. Oranye NO, Ahmad C, Ahmad N, Bakar RA. Assessing nursing clinical skills competence through objective structured clinical examination (OSCE) for open distance learning students in Open University Malaysia. Contemp Nurse. 2012;41(2):233-41. https://doi.org/10.5172/ conu.2012.41.2.233
12. Solà M, Pulpón AM, Morin V, Sancho R, Clèries X, Fabrellas N. Towards the implementation of OSCE in undergraduate nursing curriculum: A qualitative study. Nurse Educ Today. 2017;49:163-7.

13. Bouchoucha S, Wikander L, Wilkin C. Nurse academics perceptions of the efficacy of the OSCA tool. Collegian. 2013;20(2):95-100.

14. Rushforth HE. Objective structured clinical examination (OSCE): Review of literature and implications for nursing education Nurse Educ Today. 2007; 27(5): 481-90. https://doi.org/10.1016/j.nedt.2006.08.009

15. Meskell P, Burke E, Kropmans TJ, Byrne E, Setyonugroho W, Kennedy KM. Back to the future: An online OSCE Management Information System for nursing OSCEs. Nurse Educ Today. 2015;35(11):1091-6. https://doi. org/10.1016/j.nedt.2015.06.010

16. McWilliam PL, Botwinski CA. Identifying strengths and weaknesses in the utilization of Objective Structured Clinical Examination (OSCE) in a nursing program. Nurs Educ Perspect. 2012;33(1):35-9.

17. Traynor M, Galanouli D. Have OSCEs come of age in nursing education? Br J Nurs. 2015; 24(7):388-91. https:// doi.org/10.12968/bjon.2015.24.7.388

18. Bagnasco A, Tolotti A, Pagnucci N, Torre G, Timmins F, Aleo G, Sasso L. How to maintain equity and objectivity in assessing the communication skills in a large group of student nurses during a long examination session, using the Objective Structured Clinical Examination (OSCE). Nurse Educ Today. 2016;38:54-60. https://doi. org/10.1016/j.nedt.2015.11.034

19. Rush S, Ooms A, Marks-Maran D, Firth T. Students' perceptions of practice assessment in the skills laboratory: an evaluation study of OSCAs with immediate feedback. Nurse Educ Pract. 2014;14(6):627-34. https://doi. org/10.1016/j.nepr.2014.06.008

20. Selim AA, Ramadan FH, El-Gueneidy MM, Gaafer MM. Using Objective Structured Clinical Examination (OSCE) in undergraduate psychiatric nursing education: is it reliable and valid? Nurse Educ Today. 2012;32(3):283-8. https://doi.org/10.1016/j.nedt.2011.04.006

21. Byrne $E$, Smyth $S$. Lecturers' experiences and perspectives of using an objective structured clinical examination. Nurse Educ Pract. 2008;8(4):283-9. doi:10.1016/j. nepr.2007.10.001

22. Objective Structured Clinical Examination Toolkit and Guide for Administrators of IEN Programs. Available from: https://coned.georgebrown.ca/pdfs/objective-structuredclinical-examination-toolkit.pdf Retrieved: 14.02.2017. 


\section{PRIMJENA OBJEKTIVNO STRUKTURIRANOGA KLINIČKOG ISPITA U PREDDIPLOMSKOM OBRAZOVANJU MEDICINSKIH SESTARA}

\section{Sažetak}

Uvod. Objektivno strukturirani klinički ispit (OSKI) često se primjenjuje na preddiplomskom studiju sestrinstva kao sredstvo za pružanje standardizirane i objektivne procjene kliničkih vještina potrebnih za buduću profesionalnu djelatnost medicinskih sestara. Svrha je ispita OSKI pomoći studentima da ovladaju različitim kliničkim vještinama i pripremiti in za adekvatan odgovor na specifične probleme kroz simulaciju različitih scenarija iz prakse. Studenti izvode kliničke vještine u sigurnom i kontroliranom prostoru pod nadzorom mentora. Od sredine 1970-ih godina OSKI se primjenjuje za procjenu usvojenosti kliničke vještine studenata medicine. Od tada pa do danas primjenjuje se za procjenu znanja i vještina kod različitih profila zdravstvenih djelatnika, posebno medicinskih sestra.

Svrha rada. Svrha je rada predstaviti znanstvene dokaze o prednostima ispita OSKI u preddiplomskom sestrinskom obrazovanju. Cilj je rada analizirati podatke o primjeni ispita OSKI u sestrinskom obrazovanju u svijetu te istaknuti studentsku i nastavničku percepciju uporabe ispita OSKI.

Metode. Učinjen je sustavni pregled članaka objavljenih u bazi MEDLINE u periodu od 2005. do 2017. s temom primjene ispita OSKI u sestrinskom obrazovanju te percepcije studentske i nastavničke percepcije ispita OSKI.

Rezultati. U obzir je uzeto ukupno osam članaka. Ovi su članci odabrani jer pružaju informacije o primjeni ispita OSKI u sestrinskom obrazovanju te nastavničkoj i studentskoj percepciji ispita OSKI.

Zaključak. Primjena ispita OSKI ima više pogodnosti za obrazovanje studenata. S pomoću njega možemo procijeniti znanje i vještine važne za sestrinsku praksu. Pomaže za bolju pripremu studenata za njihovu profesionalnu djelatnost.

Ključne riječi: OSKI, sestrinsko obrazovanje, kliničke vještine 